\title{
Innovating the Innovation Process: An organisational experiment in Global Pharma pursuing radical innovation.
}

\author{
Peter Robbins ${ }^{1}$ and Colm O'Gorman ${ }^{2}$
}

${ }^{1}$ Peter Robbins, NUI Maynooth School of Business, Rowan House, Maynooth, Co Kildare, Ireland.Peter.Robbins@nuim.ie

${ }^{2}$ Colm O’Gorman, Dublin City University Business School, Dublin 9, Ireland.

Colm.ogorman@dcu.ie

Peter Robbins is Academic Director for Maynooth University's Eden Centre for Entrepreneurship and Design Innovation. He is a former Global Director of Innovation Excellence for a top 3 pharma company. He is a founder and Director of the Innovation Foundation, an organisation which advises corporate and public sector clients on how to enhance their capacity to innovate successfully.

Colm O'Gorman is Professor of Entrepreneurship at Dublin City University Business School. His research interests include entrepreneurship, industry evolution, and internationalisation processes in SMEs. He has published extensively in international journals. 
Innovating the Innovation Process: An organisational experiment in Global Pharma pursuing radical innovation. 


\begin{abstract}
The challenge of managing the fuzzy front-end of the innovation process is particularly acute for large, multi-brand, R\&D-intensive firms. Poor performance at generating radical innovations has resulted in many large organisations seeking to innovate how they organise for innovation. This paper presents an inductive, longitudinal study of an organisational experiment that sought to get 'game-changing, radical ideas' into the new product development funnel of a Top 3 pharma. The immediate outcomes of a team based internal innovation tournament included thirty three new product ideas, fourteen of which were radical. The medium term outcome of the experiment was a re-organisation of how the firm now pursues radical innovation activities. We link these outcomes to team leadership, contrasting innovation processes, including decisions about how to incorporate the "voice of the consumer'. The inductive, longitudinal study suggests causal interconnections between innovation team leadership, innovation team processes, and innovation outcomes.
\end{abstract}




\section{Introduction}

The challenge of managing innovation is particularly acute for large, multi-brand, R\&D-intensive firms. There is a high risk of failure, with as few as one out of every 3000 'raw' ideas achieving significant commercial success in most industries (Stevens and Burley, 1997), and outputs are often delayed, unpredictable and not consistent with customer expectations (Zheng et al, 2010). Increased competitive intensity is forcing many firms to push new products through the ideation, design and manufacturing pipeline at a faster rate, encouraging greater focus on accelerated development and compressing timelines (Kach et al, 2012).

Radical innovation is especially perilous as high-novelty new product development (NPD) projects are highly uncertain, making their front-end planning process unpredictable (Vandenbosch and Clift, 2002). By necessity, market information is scant; uncertainly is high and there are few, if any, a-priori strategies for managing these projects (Brentani and Reid, 2012). While market oriented organisations seek to reduce the risks associated with innovation by integrating the voice of the intended customer into the innovation process (Asmawi and Mohan, 2011), current customers may actually be a restraining force on radical innovation (Christensen and Raynor, 2003; Danneels and Sethi, 2003). Staff in the R\&D function can compound this complexity, as frequently they seek autonomy in their work; they may resist hierarchical control; and they tend to show more loyalty to their profession than to their employer and they often do not have an architectural understanding of business strategy and product design (Miller and Olleros, 2008). Moreover, team conflict in such projects is common. Even fundamental decisions like whether or not to proceed further with ideas varies greatly when decision-making teams are confronted with real-world cases (Cowlrick et al, 2011). 
The aim of this paper is to identify how large organisations manage the fuzzy front-end of the innovation process when the objective is to increase the flow of radical new products ideas. This is done through a longitudinal study of an organization's effort to supplement existing incremental innovations with more radical ones. The focus of the inductive study is the design and implementation of an internal innovation tournament that sought to get 'gamechanging, radical ideas' into the new product development funnel of a Top 3 pharma. The immediate outcomes of the experiment included thirty three new ideas, fourteen of which were radical. One of the two teams involved in the tournament accounted for nearly all of the radical innovations. As a direct consequence of this organisational experiment the firm have subsequently adopted separate structures for incremental and radical innovation with marketing now directing the former and R\&D leading the latter.

Despite the clear need for in-depth longitudinal studies of the innovation process, such studies are rare (Govindarajan and Trimble, 2010). The advantage of longitudinal studies is that causal interconnections between innovation leadership, innovation processes, and innovation outcomes may emerge. This inductive study involved a level of access that is very uncommon given the commercial sensitivity that generally surrounds radical innovation efforts. The study is based on data collected from thirty two interviews over a six year period. Interviews included those responsible for designing the organisational experiment, the leaders and members of the two teams that competed in the innovation tournament, those that judged the tournament, and follow up interviews with those responsible for designing how the firm has been subsequently organised for innovation in the R\&D function.

Studying this corporate experiment is important for a number of reasons. First, there is increasing evidence that large firms increasingly search for radical innovation (McLaughlin et al., 2008) given that radical innovation drives firm growth (Leifer et al, 2000), particularly in the R\&D sector (Eisenbeiss et al, 2008). Proficiency at innovating via new products 
remains not merely a key priority for many managers but arguably the ultimate dynamic capability within a firm (von Hippel, 2005). Unfortunately, large firms with a dominant position in their industry have a poor record being first to market with game-changing innovation (Christensen et al, 2004).

Second, our comparison of team initiatives is important because using teams is probably the most widely cited approach to managing the innovation process (Boyle et al., 2005). Management needs to maintain a balance between reducing the uncertainty attached to innovation activities through the implementation of rules and processes, while also encouraging creativity and innovativeness through fluid organisational structures (Aswami and Mohan, 2011). A further challenge in the R\&D setting is how to facilitate a team environment conducive to market-oriented innovation (Thamain, 2003).

Third, while team leadership is repeatedly cited as a critical component in successful firm-level innovation, the literature to date argues that this facet of the innovation process has not been adequately investigated and is 'conspicuously absent' (Mumford et al., 2002:706) or unclear (Keller, 2006; Nippa, 2006). More specifically, organisations struggle to manage teams successfully (Barczak and Wilemon, 2003), and 'the issues of staffing the innovation team and selecting the people who are going to lead the innovation process have hardly been discussed in the innovation literature' (Buijs, 2007:203).

Fourth, there is relatively little research that explores the management of the fuzzy front end of the innovation process. The fuzzy front-end of the innovation process is where new ideas are developed to a stage where nascent ideas are sifted and ranked (Hansen and Birkinshaw, 2007). Recent research suggests that the fuzzy front-end of innovation is a distinct and different stage in the innovation process and therefore organisations may need to manage this stage of the process differently (Roper et al., 2008; Brentani and Reid, 2012). 
Our inductive, revelatory study focuses on innovation process and team leadership during the fuzzy front end of an innovation process. The study suggests causal interconnections between innovation leadership, innovation processes, and innovation outcomes. The data suggests that the initial sense-making of a team leader shapes how a team manages the innovation process, which in turn, influences the nature of the innovation outcome. In our comparative study the team leader who presided over the team that ultimately generated more radical innovations espoused the supremacy of science, individual freedom and passion as the springboard for radical new ideas. This team engaged in more external networking, spent more time on idea generation, and delayed integrating the voice of the customer into the process of evaluating and prioritising radical new product ideas. In contrast, the leader of the second team, which was praised in the initial evaluation for delivering 'consumer tested' new product ideas, albeit ideas that were less original and more incremental, project managed his team. This team were more inward looking and relied to a much larger extent on the 'voice of the consumer' in forming, assessing and prioritising ideas.

Follow-up interviews with the organisation three years after the initial tournament suggest that the organisation has internalised the lessons of the experiment and innovated its approach to developing radical innovation as a consequence. The firm adopted a structural separation of the management of radical and incremental innovation. A new White Space innovation team now focuses exclusively on radical innovation. The composition of this team, and the choice of its leader, reflect the characteristics of the 'radical innovation' team from the innovation tournament.

The following account of corporate innovation begins by broadly reviewing the literature to identify the key issues involved in the management of the ideation phase of radical innovation. This is followed by a description of our longitudinal inductive study and 
the data collection process. Over the period 2007 to 2013, data was collected from thirty two interviews with senior executives, team leaders and team members. These detailed interviews provide insight into the design of the innovation tournament, the approach of the two team leaders, the experience of the team members, the organisation's assessment of the teams, in terms of which team 'won', and the changes to how the organisation pursues radical innovation. The innovation tournament and the approaches of the two teams are described and their processes analysed in detail. The paper concludes with implications for researchers and managers, setting out how organisations might manage for radical innovation during the fuzzy front end of the innovation process.

\section{Literature review}

To answer the question of how organisations can increase their output of radical new product ideas, this section defines radical innovation and what it means in the context of the organisation that is the focus of this study. It also identifies how the organisational and managerial challenges of the fuzzy front end of the innovation process might differ where the outcome sought is radical innovation.

\subsection{Defining Radical Innovation}

Innovations are often analysed in terms of extremes: incremental and radical (e.g., McDermott and O'Connor, 2002); continuous and discontinuous (Veryzer, 1998); and sustainable innovation and disruptive innovation (Christensen et al, 2004). There are many diverse descriptions of radical innovation: 'discontinuous innovation' (Anderson and Tushman, 1990); 'emerging technology' (Day and Schoemaker, 2000); 'architectural innovation' (Tushman et al, 2010); and 'disruptive' technology (Christensen et al, 2004). 
More specifically, in terms of ideas, radical innovation ideas have been defined as innovations that embody a new technology that results in a new market infrastructure (Song and Montoya-Weiss, 2001); and as innovations that create a demand previously unrecognised by the consumer (Garcia and Calantone, 2002).

Regardless of the variation in words used to describe radical innovations, some common elements are present in most definitions. Definitions of radical innovation generally allude to aspects related to high market and technological uncertainty, new market creation, new capabilities in the innovating firm, and the possibility that such innovations might cannibalise a firm's prior business model. Leifer et al. (2001) define radical innovation thus:

A radical innovation is a product, process, or service with either unprecedented performance features or familiar features that offer significant improvements in performance or cost that transform existing markets or create new ones. (p. 103)

Notwithstanding the precise nature of this definition, the degree of radicalness of an innovation is conceptually challenging to define or measure. This is particularly the case during the early stage of emergence of an innovative product idea. Categorising an innovation as either radical or incremental therefore remains somewhat subjective. There may be a continuum of innovations that range from radical to incremental with a new product or service's position on this continuum depending upon perceptions of those familiar with the degree of departure of the innovation from the state of knowledge prior to its introduction.

In the context of the experiment examined in this study, radical innovation describes new commercial ideas that have two characteristics. First, they demand new technology or new scientific know-how, new molecules for new therapy area expertise; perhaps not necessarily new to the world but new to the firm at least. Second, they should appeal to new consumer groups, new segments, new therapy areas or new patient groups. To qualify for the 
description of 'radical', in this study, ideas needed to qualify under both headings: new science for a new market.

\subsection{Managing for radical innovation at the fuzzy front end}

Research that studies innovation in terms of process is under developed in the literature (Crossan and Apaydin, 2010). Approaches to understanding the temporal sequencing of innovation typically assume that innovation projects are characterised by ideas that emerge as relatively raw, fragmentary, embryonic thoughts and connections and that these raw ideas require some level of incubation in order to develop selected nascent ideas into testable concepts. Recent research on the innovation process suggests that the innovation journey is described as a three phase process (Hansen and Birkinshaw, 2007; Roper et al., 2008). The first phase, the fuzzy front-end, describes the process of developing new ideas, variously referred to as discovery, idea generation or knowledge sourcing. The second phase describes how teams sift, prioritise and rank nascent ideas; it deals with how raw, often technical ideas are converted into tangible innovation propositions. This phase is variously referred to as the incubation, opportunity, idea conversion and transformation phase. The third phase refers to the launch, introduction or implementation of the new ideas within the organisation. This third phase is variously referred to as acceleration, realisation, idea diffusion, and exploitation as it deals largely with implementation; often with a focus on project management.

Extant studies of radical innovation typically focus on the latter stages of the innovation process, that is, the stages that follow ideation (Kach et al, 2012) with very few focusing on the idea generation phase despite the challenges of managing for radical innovation being particularly pronounced during the fuzzy front end of the innovation process (Buijs, 2007; Sarin and O'Connor, 2009). These challenges arise because radical 
R\&D innovation projects differ from incremental innovation projects in a number of ways. Radical innovation is inherently complex because typically they involve the following: high levels of technical expertise; high levels of creativity; extensive search; engagement with new, external partners; and an understanding of current and likely future market demand. These projects are risky and frequently involve unforeseen processes and as a result, setbacks and disruptions are frequent (Leenders et al, 2007). These issues are compounded by the evidence that there is no correlation between $R \& D$ expenditure and overall financial performance from innovation, hence simply investing more in $R \& D$ does not guarantee success (Holma et al., 2012).

In managing for radical innovation, the standard processes that work for incremental innovation may not be useful (Pawar et al, 2009; McDermott and O'Connor, 2002). There is evidence that some approaches to managing innovation may not be suited to radical innovation. For example, stage-gating processes may be better suited to producing small, incremental innovations (Cooper et al, 2002). Less formal management processes, including in particular, less formal assessment and evaluation criteria, may be suited to the ideation phase of radical innovations (Martinsuo and Poskela, 2011).

In designing innovations systems that are focused on radical innovation there are a number of elements that organisations need to consider. First, while a closed innovation system might deliver incremental innovation, existing literature suggests that collaborating with organisational and individual networks are more likely to yield radical innovation (Karkkainen and Ojanpera, 2006; Bahemia and Squire, 2010). More specifically, at the idea generation stage, Steiner (2009) suggests that collaborative creativity, which is, tapping into external sources of ideas, is a prerequisite for the generation of radical innovation ideas. Steiner (2009), in his call for 'open creativity', notes the particular contribution a networked, collaborative approach can make in the creative, idea-generation phase of innovation. 
Managing radical innovation projects, at the front end, is likely to demand greater levels of flexibility, responsiveness, and the incorporation of new information (Vandenbosch and Clift, 2002).

Second, a further difference in the management of radical innovation relates to the 'voice of the consumer'. While organisations are increasingly involving customers in their innovation process so that new market introductions are aligned with customer wants and needs (Leifer et al, 2000), extant research on innovation suggests that the voice of the customer is generally unhelpful in the search for radical new ideas (Christensen and Raynor, 2003; Danneels and Sethi, 2003); with only limited instances in which close customer ties have led to the commercialisation of successful, radical ideas (Fredberg and Piller, 2011). In instances where consumers have been found to be helpful in generating high-potential, novel ideas, it has been a specialist group of lead-users and not mainstream consumers (Von Hippel 2005); such users have been found to have high motivation to seek new solutions, possess a diverse set of competencies, and be embedded in a supportive environment (Lettl et al, 2006). Furthermore, in managing an innovation project, predicting likely market demand for radical innovation poses a dilemma as if the idea is genuinely highly novel, there will be no suitable benchmarks against which to compare it.

Despite the obvious leadership challenges in managing radical innovation, extant research typically understates the leadership role in the $R \& D$ process (Edmondson and Nembhardt, 2009). For example, Nippa argues that 'comprehensive reviews of the broad research on critical success factors of managing product innovation in most cases do not emphasise leadership or leadership styles explicitly' (2006, p2). While this may be true for the innovation literature, there has been considerable research conducted to examine the characteristics of the ideal R\&D team leader (Edmondson and Nembhardt, 2009; Sarin and O'Connor, 2009). While not synonymous with an innovation leader, the R\&D team leader 
represents a close proxy. This research on $R \& D$ team leaders generally propose that the team leader must have both the 'soft' people skills and the 'hard' project management skills to manage complex, often lengthy and frequently technical projects; and it increasingly identifies networking skills as a feature of the R\&D process.

Research has highlighted the management challenges involved in managing for radical innovation. These include the formality or rigidity of the processes used within teams to manage the processes of idea generation and idea prioritisation; the challenge of if, when and with what emphasis, to integrate the voice of the consumer into the innovation process; and how 'open' teams should be in the idea generation phase. These ideas about the management of radical innovation informed the inductive study of an organisation experiment to generate radical innovation. The research was guided by the following questions:

- How does a large organisation manage innovation activities at the fuzzy front-end of the innovation process where the objective is to increase the flow of radical new products ideas?

- Should approaches to managing the fuzzy front end of the innovation process be contingent on the nature of the innovation (radical or incremental) desired?

\section{Research design}

\subsection{Research method and context}

The paper summarises a revelatory, inductive study of an organisation experiment, what we refer to as the Radical Innovation Tournament (RIT), based in the R\&D division of one of the world's top three pharma firms (referred to as Pharmaco). Yin (2003) contends 
that the case study approach is essential when elaborate social situations are under scrutiny, because one of its strengths as a research methodology is that it affords a strategy for examining composite, real-life situations. The case study approach successfully manages the countless inter-related elements embedded in real-life situations, which combine to create the phenomenon. Idiographic is how Bryman (2004) expressed the nature of case study research as its aim is to expound the distinctive elements of the event under investigation, while also attending to contextual features. Case-study research is especially appropriate for research into real, complex situations (Perry, 1998) and new topic areas with a focus on 'how' or ‘why' questions (O’Connor, 1998), concerning a contemporary set of events including those relating to radical innovation. Govindarajan and Trimble favour case studies as the best way to build knowledge about innovation, arguing that 'the only way to study the management of innovation initiatives is to compile in-depth, multiyear case studies' (2010; p xiii).

Design principles for inductive qualitative studies of firms as set out by Eishenhardt and Graebner (2007) and Yin (2003) were followed in designing this study. RIT was a purpose-designed innovation tournament intended to encourage a higher level of radical innovation in new product development. Specifically the project sought to get more 'gamechanging, radical ideas' into Pharmaco's new product development pipeline. This time-bound initiative involved two teams based in separate sites, one in the UK and one in the US, competing for nine months to produce innovative ideas. The company's Global President of $R \& D$ describes the genesis of the project:

It was the first time we had a talent review process within the R\&D community and we created a category of people that we felt were 'innovative'... The question that we discussed at the talent review, well, if you've got a group of people identified as innovators, why don't we ask them to work on identifying new ideas for the company through whatever creative processes they want to? ...to work with a completely open brief, unconstrained by interference by senior management, for a period of time to generate radical ideas. 
This discussion evolved into a commitment to an organisational experiment, referred to as the Radical Innvation Tournament (RIT) which was designed to get more, novel, gamechanging ideas into the R\&D pipeline. Specifically, the teams were resourced as follows: 1012 members in each of two teams - one in UK and one in the US, with the two teams to be created equal in terms of the quality, technical expertise (almost all $\mathrm{PhD}$ 's in science disciplines) and experience (including senior management up to VP level) of personnel. The team members were required to commit to devoting at least twenty percent of their time to RIT. Each team recevied a budget of $\$ 250,000$, to be allocated however the team leaders decided. The teams could access more funds if required for specific purposes. The teams were not required to provide any report on their progress during the nine months of the project.

This experiment represents an interesting context for the study of radical innovation for several reasons. The RIT project provided access to the constructs of particular interest: radical innovation in an $\mathrm{R} \& \mathrm{D}$ context; the fuzzy front-end of the innovation process; and a team based approach to innovation. A priori, it appeared that the RIT initiative was a good context for studying the development of what the teams and the organisation considered to be 'radical' innovations. The project specifically encouraged the two teams to explore opportunities outside the organisation's existing operations. The brief to the teams required them to deliver nine discrete innovation opportunities for new products and/or services, six of which were to be rooted in current brands and therapy areas, and three were to come from new areas, new markets, possibly using technologies that were unfamiliar to the firm. Getting insights into the development of radical innovations is particularly difficult because, by its nature, radical innovation within large organisations is rare, can be difficult to identify a priori, and often takes long periods of time before it is apparent if the innovation is in fact radical. 
The nature of the RIT initiative was a good context for gaining insights into how teams manage for innovation. The design of the RIT initiative was a result of deliberate senior management choices. It is was an organisational experiment in that the two teams were provided with the same brief; were 'created equal' insofar as was possible with experience, expertise and seniority balanced across the two teams; were based in different geographic contexts (the UK and the US); where given an equal and fixed amount of time (nine-months) and budgetary resources; and the outcomes were 'judged' by senior management, with one team adjudicated to have 'won' the contest.

Another feature of the study is the access Pharmaco provided explicitly for the purposes of doing research. The motivation of senior management was that if the RIT initiative successfully produced radical innovations they wanted to understand how best they could exploit the initiative and if they could apply lessons from the initiative to other aspects of the firm's innovation process. Such access is highly unusual given both the commercial and organisational sensitivities attached to such projects.

A further feature of the study is that the industry and firm context is in and of itself of importance. This context has been the attention of focus with the literature on innovation because the pharmaceutical industry, possibly more than any other, depends on innovation for success: 'The key to long-term growth has to be R\&D pipeline success' (McNamara, 2004, p. 25). Within extant literature researchers have used case studies of firms from the pharmaceutical industry to gauge cultural enablers supporting innovation (Balsano et al., 2008), and to divide the new product innovation process into two distinct phases of early and late stage development (Bonabeau et al., 2008). Within the pharma industry decisions often need to be made based on insufficient data and with a high degree of uncertainty, acute time pressure, in an environment where decisions are costly (clinical trials etc) and, often against a competitive backdrop where several firms are vying to be first to market for a similar product 
or treatment (Cowlrick et al, 2011). The focus firm for this study is of particular importance because it is one of the world's top three pharma firms, with revenues of over $£ 30 \mathrm{bn}$, and it is one of the world's top ten R\&D spenders. The RIT initiative therefore provided a unique opportunity to gain rich insights into the development of radical innovations in a large $R \& D$ intensive organisation.

Finally, the innovation tournament was a success in two respects. First, it resulted in thirty three new product ideas, fourteen of which were radical. Some of these ideas remain in development within the company's pipeline but none have, so far, been commercialised. The majority of the ideas that were accepted into the R\&D stage-gate process came from the UK team. Second and equally importantly, the organisation internalised the lessons of the experiment and has since innovated its approach to innovation accordingly.

\subsection{Data collection and analysis}

The study is based on extensive field observation and thirty-two in-depth interviews conducted over a six year period. During the first phase of the study in 2007, seven members of the senior management team in the R\&D division were interviewed. These corporate level executives were responsible for designing the RIT initiative. The interviews provided insight into the organisational context that surrounded the decision to initiate RIT. During the second phase the two RIT team leaders and all available team members were interviewed. The interviews were framed and guided by the overall question: 'tell me about your experience with the RIT team and project'. Seventeen interviews were conducted between February 2008 and June 2009. While there had been 25 members over the entire project, some had left Pharmaco either during the project itself or very shortly afterwards.

During the third phase of the research six members of the senior leadership team in the R\&D division were interviewed. These six individuals had reviewed the work of the two 
teams involved in the RIT initiative and had evaluated the project ideas, to assess the potential of the ideas for Pharmaco, and to decide which ideas would be progressed after the RIT initiative concluded. They were the 'judges' of the RIT initiative. In the fourth phase of the field work, the divisional head of R\&D (who had been one of the judges of the RIT contest in 2009) and the head of a new unit in the innovation management group, the White Space team, were interviewed in 2013, three years after the conclusion of the project, to determine how the RIT had shaped the organisation's current approach to innovation.

In collecting data on the RIT initiative the potential bias of the interview data was reduced by interviewing over an extended period and by supplementing the interviews with extensive secondary data on the project. This included documents such as the Briefing Documents for RIT initiative prepared by the senior leadership team; the briefing presentation for the two RIT teams; team data such as final presentations, Microsoft Project Plan (US team), consumer research data such as 'BuzzBack' volumetric data on the ideas and video footage of a number of focus groups (US team); a 'close-out' report prepared by the US team; and a 'close-out' report on the project prepared by the Pharmaco's Human Resources Department. In analysing the data, each transcript was coded following a threestep process, allowing for multiple levels of insight into the context of each individual interview.

Analysis of the data followed processes used in analysing qualitative data (Miles and Huberman 1994; Yin, 2003). Analysis began with the transcribing of all interview data. This was followed by writing detailed histories or narratives of the two teams, using both the interview data and the secondary data. Using tables to organise the case data and a within case comparison, the data was coded in an 'open coding' process (Ezzy, 2002, p. 87) to identify themes that were central to the teams' experiences of 'doing' innovation. 


\section{The Innovation Experiment}

RIT was a time-bound initiative involving two teams, one in the UK and one in the US, competing for nine months to produce radical new product ideas. In following the two teams, tracking their activities and their experiences over a period of years, the study became 'A Tale of Two Cities' as the two teams and team leaders manifested different approaches to the task, and, from the perspective of Pharmaco, produced quite different outcomes.

In terms of outcomes, the two teams presented a different number and range of ideas at the final presentation event (Figure 1). Overall, the UK team presented not just more ideas overall but more ideas that could be categorised as radical.

\section{Insert:}

Figure 1. Innovation tournament outputs

Each idea was classified during the analysis as either radical or incremental. Radical ideas had to be new in terms of two criteria: new technology or new scientific know-how, new molecules for new therapy areas; and new consumer groups, new segments, new patient or therapy areas (Figure 1). By way of example, we describe ideas from two of the four catgeroies in Figure 1. Ideas were classified as incremental if they a) used an exisiting technology, mode of action, science or active ingredient within an existing brand or b) if they extended into either a new technology or new market area, but not both. As an example, if the company were looking at a market within which they already had a leading brand: i.e. smoking cessation and they came up with an idea of a nicotine mist spray - this would be considered to be incremental because the market targetted is familiar to the organisation and 
the active ingredient also familiar: nicotine. It is merely the delivery mechanism, a spray mist device, which is new.

In contrast, ideas were classified as radical if they involved Pharmaco moving both into new markets and into unfamiliar technology. These ideas propose the development of new scientific areas for exploitation in new markets (and therefore requiring new marketing competence). An example of a radical idea from the RIT project was the digital foetal monitor for expectant mum's. This is a radical idea for Pharmaco because the firm is not yet involved in the market for medical devices nor does it target expectant mums. The implementation of this idea would require the firm to build new technical capability (or alliances) and to create a new brand.

The US team were declared the winners of the RIT tournament by the judging team. In judging the outcome, the President of R\&D judged the US team to have remained closer to brief in terms of the number of ideas presented. Crucially, in his opinion, they also had commissioned some early stage market research on their ideas. The President of R\&D justified his selection as follows:

I think it is because it was structured and they [the US team] had data and they had consumer research, they had pretty much concrete data from the consumer.

However, this declaration was not the unanimous view of the R\&D senior management team, most of who felt that the UK team had delivered ideas that were far more original; far more radical and more promising from a strategic perspective (Table 1). The analysis of the data and the comparisons of the two innovation teams highlight how one team (UK) produced innovation ideas and concepts (outcomes) which were radical, while the other team's (US) outcomes were described, by the judging panel, as less original and more incremental. 


\section{Insert:}

Table 1. The outcomes: comments from the judging panel

What might explain the differences in the outputs of the two teams? The analysis of the two teams suggests that differences in the team leaders and their approach were important. The difference in process between the two teams was summarised by one member of the senior management team as follows:

The people in the UK just tend to be a lot more free spirited and less structured and that unstructured approach created a lot of conflict I think. It's a very interesting thing in the UK they never got face to face. Why? Because they could not arrange their calendars to get face to face. .......Which I think is what the US did; I think the US forced RIT to be a priority. The end of the day they both did really great. It's just when you play it back the US was more structured and it just tended to come over a bit more credible than what the UK presented but the UK was very high in creativity.

More specifically, the different approaches are summarised in Table 2 and Table 3. Table 2 provides a descriptive summary of the approach of the two teams. In Table 3 the activities of the UK and US teams are presented in terms of the key activities of the fuzzy front end of the innovation process.

\section{Insert:}

Table 2. A 'Tale of Two Cities': the UK and US team experience

\section{Insert:}

Table 3. Managing the innovation process: UK and US teams

While the RIT initiative has not been exactly replicated, the initiative had a significant impact on how innovation is managed within the organisation. The very clear delineation of 
how one team managed to produce radical ideas while the other delivered more 'sustaining momentum' incremental ideas led to an organisational rethink of how to manage a portfolio of innovation where there is a demand for both radical and incremental innovation. For incremental innovation, the new VP of R\&D explained that the organisation needs a consistent pipeline of near term, close-in innovation, which he described as supplying 'lifeblood to the brands, keeping them fresh, competitive and relevant to their consumers'. For this type of innovation, the $R \& D$ teams are aligned to the brand marketing and insight teams. These teams are charged with producing regular upgrades to the brands and products in a certain category. In terms of voice of consumer, they apply a philosophy of 'consumer at the heart of everything we do'; they conduct a lot of consumer insight work and this drives the type of projects they pursue. The output for these teams is a steady stream of incremental innovation in their core area. This represents the bulk of the innovation programme.

However, following RIT the organisation recognised a need to purposefully seek out ideas for radical innovation and a new structure was inaugurated. The new structure was a termed the White Space team. The White Space team work across all the categories in which the organisation operates and not just a single brand or therapy area and they are not limited to the types of opportunities they can pursue. The White Space team have a technical remit and therefore do not engage with consumer research. They identify and explore new technology and science and, where appropriate, they shepherd this technology into the organisation's early-stage pipeline. The White Space team is based in UK and is led by a senior R\&D scientist, whose profile is similar to the RIT UK team-leader, insofar as he is a distinguished scientist in his field and not someone with much exposure to marketing.

The White Space team has already had some notable successes. For example, they identified a new technology platform for one of the firm's leading brands and persuaded the organisation to invest over $\$ 100 \mathrm{~m}$ to acquire the technology platform. This gave the brand a 
new, higher level of performance that represented a step-change in the market, making it the first $\$ 1$ bn brand within this division of the organisation.

Another development in the innovation process that owes its genesis to RIT is the new Open Innovation team. This team reports into the commercial division and uses a global team of technology scouts to search round the world for opportunities in research institutes, universities, small start-up technology firms, inventors and any other potential sources of novel, original and possibly radical new ideas. The Open Innovation team work closely with the White Space team with one looking at the science and the other looking at the commercial implications. While RIT was designed as an organisational experiment intended to solve a temporary drought in the company's innovation pipeline, it has turned out to be the catalyst for considerable change in how this global organisation manages its innovation programme.

\section{Results}

Analysis of the organisational experiment suggests that the teams differed in terms of how they approached three activities: managing the idea generation process; managing the process of idea prioritisation; and managing the voice of the customer during the fuzzy frontend. These differences reflect the initial interpretation by the team leader of innovation at the fuzzy front end. The results suggest that there may be a configuration logic to team based idea generation during the fuzzy front end of the innovation process in an R\&D environment (Figure 2).

\subsection{Innovation leadership: interpreting innovation at the fuzzy front end}

It is evident from the study that the two team leaders interpreted their role and that they approached the RIT initiative in different ways. While this might have been avoided by 
corporate level intervention, in this contest as with many other corporate innovation efforts, the widespread admonition to not overly direct innovation processes was adhered to. Yet, as already indicated, subsequent decisions were highly dependent on the initial sense-making of each leader.

The UK team leader was a scientist and approached the brief with the intent of staying focused on the science as a source of new ideas and allowing technology drive the outputs. He stated:

I felt, as a bunch of scientists, that we should at least stick with our scientific heritage, try and look at science in a different way, come up with novel technical solutions. The philosophy was rather than have a process whereby you go through different stats to try and pull ideas together, is you create an environment where people have the opportunity to read about new areas, talk to experts in different areas, interact with different people such that they can generate threads for their own development....... This was my way of thinking; it was shared, I would say, by half the team and I'd say the other half of the team really struggled with it.

Reflecting this view of the process resulted in the UK team leader actively avoided any formal processes; championing the excellence of science and challenging his team to engage externally with experts in science so that they would develop new insights. The team immersed themselves in the process of generating new radical ideas. The team leader focused primarily on the process of generating ideas, with the team not performing any structured idea evaluation, idea ranking or activities aimed at embedding the new ideas into the organisation, on the assumption that these were not within tournament boundaries

In contrast, the US team leader was experienced at managing projects within Pharmaco, and his approach to the project was that the team should deliver specifically on the project brief. He described his approach as follows:

When I kicked off the meeting, I had a very clear vision in my mind of what we wanted to be in a position to present to SLT (Management) nine months later. And, it wasn't 
just some ideas that have been bounced off a couple of consumers perhaps, or bounced off internal people. I wanted to be able to bring forward quantitatively tested concepts of new product ideas that we had actually thought through on the technical side and had clear approaches on how we would go about the whole thing technically. But I wanted to make sure we had the consumer heartbeat established to the point that we had some quantitative concept consumer test results on that.

The US team, which primarily produced incremental ideas directed toward existing customer segments engaged in a structured approach that sought to manage the project in terms of separate stages. They spent about one quarter of their time at the ideation stage, and then moved to ranking and prioritisation. They invested significant time and budget to the testing of their ideas with consumers and used this information to help them prioritise among the ideas they had identified.

The data suggests that the 'laissez faire' approach adopted by the UK team leader allowed individuals to develop more radical innovative ideas. The converse also holds, with the more structured management approach adopted by the US team leader delivering a suite of incremental innovative ideas. The contrast in the US and UK team experiences suggests that the organisational challenge of simultaneously delivering incremental and radical new ideas may require separate organisation structures to allow for differences in how the innovation process is managed.

\subsection{Innovation process: generating new radical ideas}

The two teams contrast significantly in terms of the internal and external networks they developed over the life of the project. In developing ideas, the UK team actively engaged in discussions with internal experts and external collaboration partners (Table 3). The first action undertaken by the UK team leader was to brief the project out to an innovation intermediary. He contacted an innovation agency, specialising in open innovation, working in the healthcare field, based in the UK but with links internationally, and gave them the same 
brief he had been given as the RIT project mandate. This gave the UK team access to novel ideas and technologies. The second action of the UK team leader was to encourage and facilitate his team members to go out and meet with experts in the fields in which they were interested. For example, The Sleep Laboratory, a UK Sleep Research Centre, became a contributor to some of the ideas proposed by the UK team. The UK team actively sought input and novel ideas from external experts and partners. The UK team leader also arranged for internal organisation experts from the marketing function to present on emerging therapy areas.

In contrast, according to the US team leader, at the start the US team 'just sat around the table and tossed ideas out and, you know, kind of wild and wacky stuff, the crazier the better'. The US team leader favoured a high level of process and began to mechanise the ideation process by adopting a software package which facilitated online sharing of ideas and allowed team members to add online to the ideas of others. The US team remained largely self-sufficient, confining their ideation activities to within the group and not engaging with external experts except on one occasion to help validate an idea already under team discussion (Table 3). Their meetings were closed in that they did not invite people in to share their ideas nor did they engage in any purposeful outreach programme in developing their ideas.

The UK team was able to infuse the innovation process with external ideas in a deliberate way within the context of this nine month tournament. Organisations engaged in efforts to switch from a closed to an open innovation model of innovation may be able to achieve some of the benefits of open innovation during the early phases of the innovation process by allowing and supporting teams that pursue an open model of innovation. That is, the data suggests that in some regards it may be quite straightforward and relatively swift for 
units or teams to switch from a closed to an open innovation model of innovation, at least in terms of the fuzzy front-end of the innovation process.

\subsection{Innovation process: the prioritisation of ideas}

The RIT project ran for 9 months. The US team leader designated the first 9 weeks for ideation, that is, for generating, building upon and gathering new ideas. From week 10, the US team moved into idea prioritisation (Table 3). By contrast, the UK team expended the full 9 months on the Ideation or Idea Generation phase. Irrespective of the decision regarding the time committed to idea generation, the brief required each team to prioritise their ideas, as only nine ideas were to be presented at the final presentation. For both teams prioritising the ideas was problematic. It was single activity that, according to the interviews with team members, that generated the most disharmony and conflict within the teams. The US team allowed feedback from consumers to guide their decisions about which projects to progress and which to abandon. They did qualitative focus-groups and then early-stage, volumetric, online, quantitative research. They did not exercise any personal judgment about the quality of individual ideas; if consumers liked an idea, it stayed in.

In contrast the UK leader took the view that passion would be the filter. In his words:

If somebody had genuine heart and enthusiasm for an idea, they were allowed to run with it, which actually I think is the right way of doing it because, remember, we're doing it from a scientific perspective. So some of the areas of science would not have been strengths of everyone on the team ... there had to be an element of trust.

However, this did not work from the perspective of some members of the UK team. The following comments from three members of this team suggest that they did not believe the best ideas made it to the final presentation: 
If you fire up twelve or thirteen individuals who are supposed to be relatively creative and tell them to all go get their own ideas, then how do you then sit them down and argue which ideas do you take forward and which ideas do you leave behind? And do that in a way that divorces personalities and egos from it, is always quite tricky.

This is where the system failed - because we had lots of very strong ideas. Some of them made it through because of the power of the personality rather than the strength of the idea itself.

There were ideas that were very personal to members of the group and largely went through purely on the strength of the passion the individual had for the idea. Personalities came into play too much.

The study suggests that while the voice of the consumer may help in prioritising incremental ideas, the passion and influence of individuals' may matter more during the early phase of the process when radical innovations are required. Managing the tension between the need to select among competing ideas and allowing the preferences and passions of individuals to 'push' ideas was difficult for both teams. Overall, the study suggests that the team leader that allowed the passion of individual team members to drive the innovation process and that effectively 'postponed' the prioritisation stage, produced more radical ideas.

\subsection{Innovation process: managing the voice of the customer}

The team leaders approached the issue of how to integrate the voice of the consumer into the idea generation process from very different and contrasting perspectives. The UK team leader eschewed market research altogether, while the US team leader spent consider time and effort integrating the voice of the consumer into the process, and allowing consumer research dictate go/no-go decisions in the project. The US team leader was most enthusiastic about the prospect of his team interacting with potential customers for their ideas, believing that it would be a significant learning experience for his team. Specifically he stated: 
Few on the team, if any had ever even attended a focus group as a viewer, not to mention actually leading one; in the front room with consumers and talking with them. People found that to be extremely valuable.

From the perspective of US team members, the experience of integrating with consumers was generally perceived as positive. For example,

The experience of talking to consumers was very uplifting, energising, very motivating, very, very - there was an end goal in mind and that was very powerful.

It (market research, focus-groups) was not quite as foreign to me I had done lot of that, but it was really fun to watch some of the people on the team who had never done it. Because you could see the light bulbs come on. It was truly an epiphany.

In contrast, the UK team leader refused to dilute the focus on raw science. He did not wish to compromise any of the potentially ground-breaking and radical ideas they had by seeking consumer feedback. He believed that the strength of his team was their scientific background and he questioned why would one bother to "make a second rate market researcher out of a first-rate scientist?' He stated:

The thrust of what we were trying to do was very much get into the science, rather than doing a balance between science and consumer research.

This study suggests that placing consumers at the heart of the innovation process and using them to decide which ideas to progress and which ones to abandon is likely to lead to ideas of an incremental nature.

\section{Insert:}

Figure 2. A configuration perspective to team based idea generation during the fuzzy front end of the innovation process in an $R \& D$ environment 


\section{Conclusion}

\subsection{Contributions to research}

Based on a systematic review of prior literature, Crossan and Apaydin (2010) argue that previously missed causal connections should emerge from studying three sequential components of innovation: innovation leadership; innovation as a process; and innovation outcomes. The inductive approach of this study allowed such causal connections to emerge. Specifically, this study shows how a well-established idea, that radical new product ideas (innovation outcomes) benefit by being separated from normal corporate routines (for example, skunk works: Huston and Sakkab, 2006) can be linked to differences in how innovation is managed (innovation processes), which reflect differences in the sense-making of the team leader (innovation leadership).

First, in terms of innovation process, the study confirms that when a team leader prioritises external networking, the efforts are more likely to lead to radical innovation ideas. This finding is in line with prior research (Karkkainen and Ojanpera, 2006; Bahemia and Squire, 2010). In particular, in terms of idea generation, firms may need to engage in 'open creativity'. Steiner (2009) argues that “open creativity” is for creativity, what Chesbrough's “open innovation” is for innovation' $(2009, \mathrm{p} .5)$.

Second, the study suggests that integrating the voice of the customer into the process of idea evaluation and prioritisation is more suited to efforts to generate incremental innovation outcomes. Desouza et al. (2008) assert that organisations are increasingly innovating in partnership with their customers thereby subtly changing their innovation strategies from 'innovating for customers' to 'innovating with customers'. Many firms fear that if the voice of the customer is absent from the innovation process, there is a high risk that the project will 
be so divorced from consumer wants and needs that it will fail to be aligned to the market (Leifer et al, 2000) and such ideas will be difficult for an organisation to embrace. High customer involvement may be a constraint on radical changes in an organisation's market offerings and/or business models (Christensen and Raynor, 2003; Danneels and Sethi, 2003). So while customers can assist in the generation of new product ideas, they are unlikely to propose breakthrough ideas (Dell'Era et al, 2011). The inconclusiveness of this debate about the role of the consumer in the innovation process may reflect a failure to differentiate between the nature of the innovation sought. While the voice of the consumer may help in prioritising ideas, the passion and influence of other actors in the process may matter more during the early phase of the innovation process when radical innovations are required.

Third, this study addresses an important gap in the literature regarding the link between leadership and the outputs of innovation teams (Ancona and Caldwell, 2007; Sarin and O'Connor, 2009). While prior literature has explored leadership in innovation, research typically fails to identify the differential efficacy of leadership styles at the different phases of the innovation process or for different innovation outcomes. The study suggests that the appropriateness of leadership approach may be contingent on the objective of the innovation process, at least during the fuzzy front-end of the process. A leader that emphasises the role of the individual and that minimises formal management processes may be appropriate at the early idea generation phase where the outcome sought is radical innovation. Such an approach may result in more experimentation and higher tolerance of risk taking and failed ideas, factors associated with successful innovation team leadership (West and Anderson, 1996). In contrast, a leader that focusses on 'project managing' the innovation process may be most appropriate where the objective is to generate incremental innovation ideas.

In conclusion, this inductive study suggests a tentative causal connection between innovation leadership, innovation processes, and innovation outcomes in the context of 
radical new product ideas in an $R \& D$ setting. More specifically, the data suggests that in the context of a specific organisational innovation initiative, the development of innovative ideas during the fuzzy front end of the innovation process can be described in terms of configurations of innovation leadership and aspects of the innovation process - how the teams approached the discovery and generation of new ideas, how they chose among competing ideas, and how they embedded the ideas into the organisation. Specifically, the case data suggests two configurations of innovation leadership, innovation process and innovation outcome. A configuration of a team leadership approach that championed the individual and 'science' in generating and choosing among ideas and that sought external new external involvement in the process of generating ideas, was associated with more radical innovation ideas. A configuration of a team leadership approach that focused on managing the process and that sought to involve the needs of the consumer and the voice of the consumer in the process of generating and selecting ideas was associated with more incremental ideas.

While aspects of these casual connections may reflect the specifics of the context, in particular the nature of the organisation (a large, global $R \& D$ intensive firm, where $R \& D$ is considered to be an engine of innovation), the location of the initiative in the R\&D function, and the time-bound nature of the innovation tournament, we argue that the connections and configurations are consistent with existing theories of creativity and innovation. Theoretically, the team leaders might have influenced innovation outcomes because of how they influenced the organisational context. This suggests that organisational context, as influenced by the team leader, created the context that individuals could generate radical ideas. Theories of creativity and innovation, such as Amabile's componential theory of creativity (1988), suggest that both aspects of the social context and of the individual (domain relevant skills, creativity-relevant processes, and intrinsic task motivation) determine levels of creativity and innovation. While individual level factors might have influenced the 
outcome of the innovation tournament, in designing the innovation tournament both teams were comprised of individuals that senior management believed were capable of delivering radical innovations, with prior performance at innovation determining why some members were invited to participate in the tournament.

\subsection{Implications for managers}

How do large organisations manage innovation activities at the fuzzy front-end of the innovation process where the objective is to increase the flow of radical new products ideas? While extant literature argues for the importance of innovation, the literature often neglects to address exactly how this should be done (Katzenbach and Smith, 2007). Prior research has identified an inventory of factors which are believed to support radical innovation. However an unintended consequence of this is that managerial guidelines become fragmented (Igartua et al., 2010). Indeed, it could be argued that the several decades of research into how to manage the innovation process have failed to provide clear and consistent findings or coherent advice for managers (Tidd, 2001). This research has specific implications for organisations and managers, who participate in, use, commission, or manage $R \& D$ teams to deliver on innovation objectives.

First, in designing innovation activities organisations should consider the nature of the innovation outcome desired, radical or incremental. Structural separation of the responsibility for incremental and radical innovation may help generate more radical innovations ideas. Specifically, separating the fuzzy front end phase of initiatives aimed at generating radical innovations may allow the organisation to adopt different, and less formal, process and may allow senior managers responsible for staffing innovation projects to vary leadership approach, or leaders. 
Second, organisations can generate radical innovative ideas in a relatively short period of time through the use of team based innovation initiatives. The study highlights that 'opening' the innovation process within a specific project context can occur relatively easily and quickly. Therefore, organisations engaged in efforts to switch from a closed to an open innovation model of innovation may be able to achieve some of the benefits of open innovation during the early phases of the innovation process by allowing and supporting teams that will pursue an open model of innovation. That is, the data suggests that in some regards it may be relatively straightforward for organisations to switch from a closed to an open innovation model of innovation, at least in terms of developing radical ideas. Organisations may also be able to jump start the innovation process. A time compressed organisational initiative such as the tournament described in this study can channel the expertise of R\&D staff in ways that facilitate the rapid development of new radical ideas.

Third, in terms of the management of R\&D innovation teams responsible for generating radical ideas, team leaders should encourage team members to engage in new internal and external information seeking activities. This should bring the benefits of external information flow into the organisation by harnessing the capabilities of individual R\&D specialists to assimilate and apply this knowledge in the context of the organisation's existing knowledge base and capabilities. Therefore, $R \& D$ team members should purposefully supplement their existing knowledge with new knowledge from (new) external knowledge sources.

Finally, organisations should consider carefully the role of customer interaction in the process. It would appear that higher focus on customer interaction is likely to guide efforts towards incremental changes to existing offerings and conversely leaving consumers out of the process may run the risk of generating ideas which are not aligned with market wants and needs. Once firms have designated their objective for a specific innovation target, whether radical or incremental, this should guide the level of consumer interaction they undertake. 


\subsection{Limitations and future research}

The findings of our inductive case study need to be considered in the context of limitations. First, the study revolves around a single-case design, with the case situated within the R\&D department of a major pharma firm. Both R\&D itself (Mumford et al., 2002) and the pharmaceutical industry (McNamara, 2004) have singular characteristics associated with them which may make findings in this area less generalisable. Second, radical innovation is difficult to study as radical ideas may not be recognised as such during the early stages of the innovation process. While the follow-up interviews show that some of the radical ideas have already influenced the firm's product portfolio, other ideas may take longer to develop. Therefore it is difficult to assess the success of the tournament in terms of implemented new radical ideas. Third, in respect to the innovation process we focussed on a singular intervention in isolation. We did not consider how the tournament impacted on other aspects of the organisation or on the team members. For example, we do not know if engaging in the tournament impacted on the individual team members job performance, whether negatively or positively, during or after the tournament. The case data suggests that for some members, the experience of the tournament was not positive, with members withdrawing from the process. Fourth, the inductive nature of this study meant that we did not, ex ante, privilege the role of the team leader. Results suggest that the team leader is an important causal determinant of both innovation process and innovation outcomes. Future studies of innovation could include a more explicit focus on the team leader and on team leadership, including a focus on the cognitive and behavioural aspects of team leadership.

Given the absence of detailed cases that explore the causal relationships between innovation leadership, innovation process, and innovation outcomes, further research is required. Such research should be across a broader range of organisational contexts. 


\section{References}

Amabile, T.M. (1988) A Model of Creativity and Innovation in Organizations. Research in Organizational Behavior, 10, 123.

Ancona, D.G. and Caldwell, D. (2007) Improving the Performance of New Product Teams. Research Technology Management, 50, 5, 37-43.

Anderson, P. and Tushman, M.L. (1990) Technological Discontinuities and Dominant Designs: A Cyclical Model of Technological Change. Administrative Science Quarterly, 35, 4, 604-633.

Asmawi, A. and Mohan, A.V. (2011) Unveiling Dimensions of Organizational Culture: An Exploratory Study in Malaysian R\&D Organizations. R\&D Management, 41, 5, 509-523.

Bahemia, H. and Squire, B. (2010) A Contingent Perspective of Open Innovation in New Product Development Projects. International Journal of Innovation Management, 14, 4, 603-627.

Balsano, T.J., Goodrich, N.E., Lee, R.K., Miley, J.W., Morse, T.F., and Roberts, D.A. (2008) Identify your innovation enables and inhibitors. Research Technology Management, 51, 6, 23-33.

Barczak, G. and Wilemon, D. (2003) Team member experiences in new product development: views from the trenches. $R \& D$ Management, 33, 5, 463-479.

Bonabeau, E., Bodick, N., and Armstrong, R.W. (2008) A more rational approach to newproduct development. Harvard Business Review, 86, 3, 96-102.

Boyle, T.A., Kumar, U. and V. Kumar (2005) Organizational contextual determinants of cross-functional NPD team support. Team Performance Management, 11, 1, 27-39.

Brentani, U. and Reid, S.E. (2012) The Fuzzy Front-End of Discontinuous Innovation: Insights for Research and Management. Journal of Product Innovation Management, 29, $1,70-87$. 
Buijs, J. (2007) Innovation Leaders Should be Controlled Schizophrenics. Creativity \& Innovation Management, 16, 2, 203-210.

Christensen, C.M. and Raynor, M.E. (2003) Creating A Killer Product. Forbes, 172, 8, 8284.

Christensen, C.M., Anthony, S.D. and Roth, E.A. (2004) Seeing What's Next - Using the theories of innovation to predict industry change. Harvard Business School Press, Boston: Mass.

Cooper, R.G., Edgett, S.J. and Kleinschmidt, E.J. (2002) Optimizing the Stage-Gate Process: What Best-Practice Companies Do-II. Research Technology Management, 45, 6, 43-49.

Cowlrick, I., Hedner, T., Wolf, R., Olausson, M. and Klofsten, M. (20110 Decision-making in the pharmaceutical industry: analysis of entrepreneurial risk and attitude using uncertain information. R\&D Management, 41, 4, 321-336.

Crossan, M.M. and Apaydin, M. (2010) A Multi-Dimensional Framework of Organizational Innovation: A Systematic Review of the Literature. Journal of Management Studies, 47, 6, $1154-1191$.

Danneels, E. and Sethi, R. (2003) Antecedents of New Product Program Creativity: the Moderating Role of Environmental Turbulence, Academy of Management Proceedings, A1-A6.

Day, G.S. and Schoemaker, P.J. (2000) Avoiding the Pitfalls of Emerging Technologies. California Management Review, 42, 2, 8-33.

Dell'Era, C., Buganza, T., Fecchio, C. \& Verganti, R. (2011) Language Brokering: Stimulating Creativity during the Concept Development Phase. Creativity \& Innovation Management, 20, 1, 36-48. 
Desouza, K.C., Awazu, Y., Jha, S., Dombrowski, C., Papagari, S., Baloh, P. and Kim, J.Y. (2008) Customer-Driven Innovation. Research Technology Management, 51, 3, 35-44.

Edmondson, A.C. and Nembhard, I.M. (2009) Product Development and Learning in Project Teams: The Challenges Are the Benefits. Journal of Product Innovation Management, 26, $2,123-138$.

Eisenbeiss, S.A., van Knippenberg, D. and Boerner, S. (2008) Transformational Leadership and Team Innovation: Integrating Team Climate Principles. Journal of Applied Psychology, 93, 6, 1438-1446.

Eisenhardt, K.M. and Graebner, M.E. (2007) Theory Building from Cases: Opportunities and Challenges. Academy of Management Journal, 50, 1, 25-32.

Ezzy, D. (2002) Qualitative Analysis: Practice and Innovation. Allen \& Unwin, Australia. Fredberg, T. and Piller, F.T. (2011) The paradox of tie strength in customer relationships for innovation: a longitudinal case study in the sports industry. $R \& D$ Management, 41, 5, 470484.

Garcia, R. and Calantone, R. (2002) A critical look at technological innovation typology and innovativeness terminology: a literature review. Journal of Product Innovation Management, 19, 2, 110-132.

Govindarajan, V. and Trimble, C. (2010) The other side of Innovation - solving the execution challenge, (First edn), Harvard Business Press, Boston, Massachusetts.

Hansen, M.T. and Birkinshaw, J. (2007) The Innovation Value Chain. Harvard Business Review, 85, 6, 121-130.

Holman, R., Jaruzelski, B. and Loehr, J. (2012) The 2012 Global Innovation 1000 Study: “Making Ideas Work”, Booz \& Co., New York.

Huston, L. and Sakkab, N. (2006) Connect and develop. Harvard Business Review, 84, 3, 5866. 
Igartua, J.I., Garrigós, J.A. and Hervas-Oliver, J. (2010) How Innovation Management Techniques Support an Open Innovation Strategy. Research Technology Management, 53, $3,41-52$.

Kach, A., Azadegan, A. and Dooley, K.J. (2012) Analyzing the successful development of a high-novelty innovation project under a time-pressured schedule. $R \& D$ Management, 42 , $5,377-400$.

Kärkkäinen, P. and Ojanperä, T. (2006) Pushing technology to where the market will be: the case of Nokia. International Journal of Technology Management, 34, 3, 203-216.

Katzenbach, J.R. and Smith, D.K. (2005) The Discipline of Teams. Harvard Business Review, 83, 7, 162-171.

Keller, R.T. (2006) Transformational Leadership, Initiating Structure, and Substitutes for Leadership: A Longitudinal Study of Research and Development Project Team Performance. Journal of Applied Psychology, 91, 1, 202-210.

Leenders, R.T.., Kratzer, J. and Van Engelen, J.M. (2007) Innovation team networks: the centrality of innovativeness and efficiency.

Leifer, R., McDermott, C.M., O'Connor, G., Peters, L., Rice, M.P. and Veryzer, R. (2000) Radical Innovation: How Mature Companies Can Outsmart Upstarts, (First edn), Harvard Press, Boston, Mass.

Leifer, R., O'Connor, G.C. and Rice, M. (2001) Implementing radical innovation in mature firms: The role of hubs. Academy of Management Executive, 15, 3, 102-113. Lettl, C., Herstatt, C. and Gemuenden, H.G. (2006) Users' contributions to radical innovation: evidence from four cases in the field of medical equipment technology, $R \& D$ Management, 36, 3, 251-272. 
Martinsuo, M. and Poskela, J. (2011) Use of Evaluation Criteria and Innovation Performance in the Front End of Innovation. Journal of Product Innovation Management, 28, 6, 896914.

McDermott, C.M. and O'Connor, G.C. (2002) Managing radical innovation: an overview of emergent strategy issues. Journal of Product Innovation Management, 19, 6, 424-438.

McLaughlin, P., Bessant, J. and Smart, P. (2008) Developing an organisation culture to facilitate radical innovation. International Journal of Technology Management, 44, 3, 298 323.

McNamara, L. (2004) In search of double-digit revenue growth: Can big pharma hit its numbers? International Journal of Medical Marketing, 4, 1, 18-26.

Miles, M. and Huberman, A. (1994) Qualitative Data Analysis: An Expanded Sourcebook, (Second Edition), SAGE Publications, Thousand Oaks, London UK.

Miller, R. and Olleros, X. (2008) To Manage Innovation, Learn the Architecture. Research Technology Management, 51, 3, 19-27.

Mumford, M.D., Scott, G.M., Gaddis, B. and Strange, J.M. (2002) Leading creative people: Orchestrating expertise and relationships. Leadership Quarterly, 13, 6, 705-750.

Nippa, M.C. (2006) Lessons from the Search for the Perfect R\&D Leader. Academy of Management Annual Meeting Proceedings, P1-P6.

O'Connor, G.C. (1998) Market Learning and Radical Innovation: A Cross Case Comparison of Eight Radical Innovation Projects, Journal of Product Innovation Management, 15, 2, 151-166.

Pawar, K.S., Beltagui, A. and Riedel, J.C. (2009) The PSO triangle: designing product, service and organisation to create value. International Journal of Operations \& Production Management, 29, 5, 468-493. 
Perry, C. (1998) Processes of a case study methodology for postgraduate research in marketing, European Journal of Marketing, 32, 9, 785-802.

Roper, S., Du, J. and Love, J.H. (2008) Modelling the Innovation Value Chain. Research Policy, 37, 6, 961-977.

Sarin, S. and O'Connor, G.C. (2009) First among Equals: The Effect of Team Leader Characteristics on the Internal Dynamics of Cross-Functional Product Development Teams. Journal of Product Innovation Management, 26, 2, 188-205.

Song, M. and Montoya-Weiss, M. (2001) The Effect of Perceived Technological Uncertainty on Japanese New Product Development. Academy of Management Journal, 44, 1, 61-80.

Steiner, G. (2009) The Concept of Open Creativity: Collaborative Creative Problem Solving for Innovation Generation - a Systems Approach. Journal of Business \& Management, 15, $1,5-33$.

Stevens, G.A. and Burley, J. (1997) 3,000 Raw Ideas = 1 Commercial Success!. Research Technology Management, 40, 3, 16-27.

Thamhain, H.J. (2003) Managing innovative R\&D teams. $R \& D$ Management, 33, 3, 297-311.

Tidd, J. (2001) Innovation management in context: environment, organization and performance. International Journal of Management Reviews, 3, 3, 169-183.

Tushman, M., Smith, W.K., Wood, R.C., Westerman, G. and O'Reilly, C. (2010) Organizational designs and innovation streams. Industrial \& Corporate Change, 19, 5, $1331-1366$.

Vandenbosch, M. and Clift, T. (2002) Dramatically reducing cycle times through flash development. Long Range Planning, 35, 6, 567-589.

Veryzer Jr., R.W. (1998) Discontinuous Innovation and the New Product Development Process. Journal of Product Innovation Management, 15, 4, 304-321.

von Hippel, E. (2005) Democratizing Innovation, (first edn), MIT Press, USA. 
West, M.A. and Anderson, N.R. (1996) Innovation in Top Management Teams. Journal of Applied Psychology, 81, 6, 680-693.

Yin, R.K. 2003, Case Study Research, (3rd edn.) Sage Publications, London.

Zheng, W., Khoury, A.E. and Grobmeier, C. (2010) How do leadership and context matter in R\&D team innovation? A multiple case study. Human Resource Development International, 13, 3, 265-283. 
Figure 1. Innovation tournament outputs

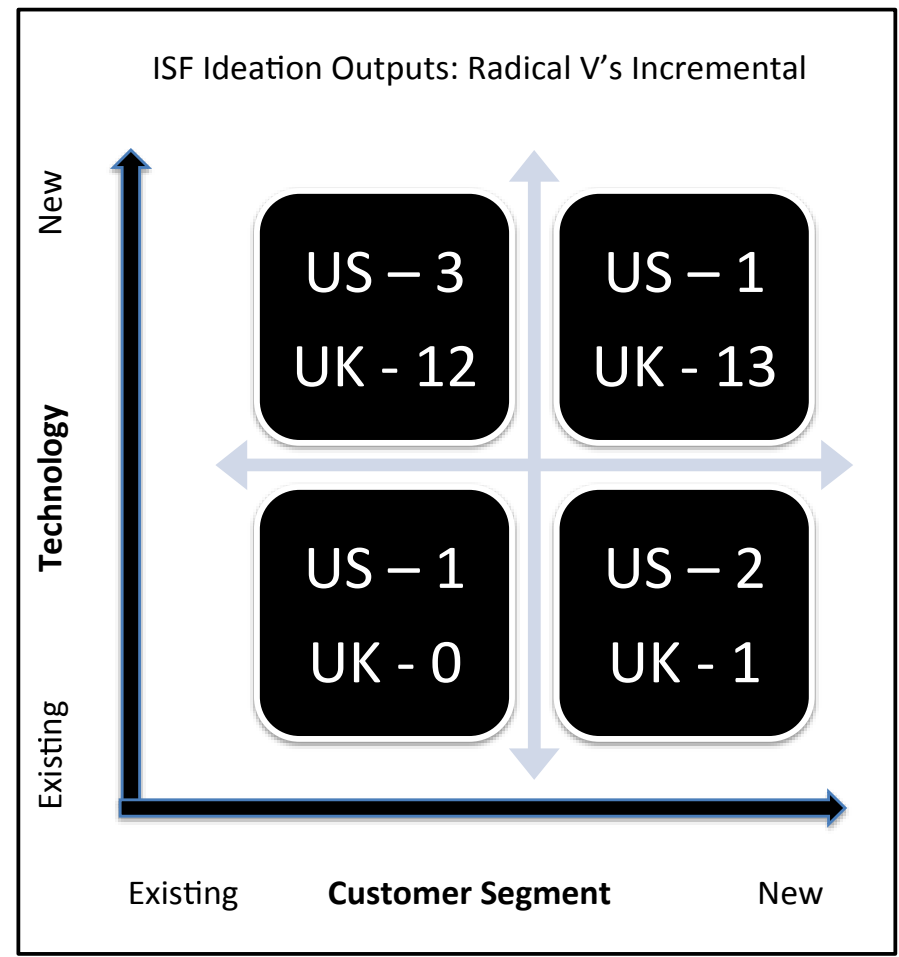


Figure 2. A configuration perspective to team based idea generation during the fuzzy front end of the innovation process in an $R \& D$ environment.

\begin{tabular}{|c|c|c|c|}
\hline $\begin{array}{l}\text { Organisation of the } \\
\text { innovation project }\end{array}$ & $\begin{array}{l}\text { Innovation team } \\
\text { leadership }\end{array}$ & Innovation team processes & $\begin{array}{l}\text { Innovation } \\
\text { outcomes }\end{array}$ \\
\hline \multirow{2}{*}{$\begin{array}{l}\text { Once-off initiative } \\
\text { Open brief: } \\
\text { - 'Game changing } \\
\text { ideas' } \\
\text { - No reporting } \\
\text { requirements- 'free } \\
\text { agenda' }\end{array}$} & \multirow{2}{*}{$\begin{array}{l}\text { Manages the } \\
\text { initiative as a } \\
\text { 'project': focus on } \\
\text { process } \\
\text { Team consensus } \\
\text { Focus on consumer } \\
\text { needs }\end{array}$} & $\begin{array}{l}\text { Engagement focused on existing } \\
\text { stakeholders and internally orientated }\end{array}$ & \multirow[t]{2}{*}{$\begin{array}{l}\text { Incremental } \\
\text { ideas }\end{array}$} \\
\hline & & $\begin{array}{l}\text { Voice of the consumer integrated into idea } \\
\text { generation and filtering }\end{array}$ & \\
\hline \multirow{3}{*}{$\begin{array}{l}\text { Teams: } \\
\text { - } 10-12 \text { staff } \\
\text { - Mixed levels of } \\
\text { seniority } \\
\text { - Scientists }\end{array}$} & \multirow{3}{*}{$\begin{array}{l}\text { Laissez-faire: } \\
\text { allows individuals } \\
\text { pursue own } \\
\text { interests } \\
\text { Focus on science }\end{array}$} & Active engagement with external parties & \multirow{3}{*}{$\begin{array}{l}\text { Radical ideas- } \\
\text { new technology } \\
\text { and new } \\
\text { markets }\end{array}$} \\
\hline & & Ideas filtered by members 'passion'. & \\
\hline & & $\begin{array}{l}\text { Delayed use of the 'voice of the } \\
\text { consumer': used to 'road test' team's ideas }\end{array}$ & \\
\hline
\end{tabular}


Table 1. The outcomes: comments from the judging panel

\begin{tabular}{|c|c|c|}
\hline & Comments on US Team Outputs & Comments on the UK Team Outputs \\
\hline $\begin{array}{l}\text { President } \\
\text { of R\&D }\end{array}$ & \multicolumn{2}{|c|}{$\begin{array}{l}\text { Honestly the edge went to the US team. I think it is because it was structured and they had } \\
\text { consumer research; they had pretty much concrete data from the consumer. They ran it } \\
\text { like you should run a project. Their structured approach was very much on brief. They } \\
\text { came up with the ideas they were tasked with. } \\
\text { The UK just looked exclusively at new businesses - the UK said, no, we're going to go } \\
\text { after the big ideas, we're not going to spend time on the incremental ideas. And that was } \\
\text { just the way it unfolded. }\end{array}$} \\
\hline Judge 1 & $\begin{array}{l}\text { I was expecting more and better science } \\
\text { from scientists. They (US) diluted the } \\
\text { science by engaging with consumers. } \\
\text { We would have preferred just to judge } \\
\text { the science. }\end{array}$ & $\begin{array}{l}\text { To me, I was very impressed by the UK team. } \\
\text { UK presented more radical concepts and } \\
\text { ideas- I don't think they included any } \\
\text { consumer research ok. ... Ok but they } \\
\text { presented many really great ideas actually. I } \\
\text { was very impressed with the concept and the } \\
\text { ideas that they have developed. }\end{array}$ \\
\hline Judge 2 & $\begin{array}{l}\text { What I saw was that a lot of effort had } \\
\text { been directed towards consumers - what } \\
\text { I was looking for was far more of the } \\
\text { scientists and far less of scientists trying } \\
\text { to run focus groups. I didn't find this } \\
\text { refreshing because a lot of money and a } \\
\text { lot of effort went into this ISF project. I } \\
\text { didn't think this was approprate because } \\
\text { this was not a training exercise. As } \\
\text { scientists, they ought to have focussed } \\
\text { exclusively on the science and not got } \\
\text { bogged down in marketing. }\end{array}$ & $\begin{array}{l}\text { The UK team's ideas were more creative } \\
\text { although I suspect we could have had a } \\
\text { fraction more process, but overall it didn't } \\
\text { matter too much. I think it was better to have } \\
\text { less process and keep the ideas free flowing, } \\
\text { the chaotic bit of it going, than have more } \\
\text { process and stifle the creativity. }\end{array}$ \\
\hline Judge 3 & $\begin{array}{l}\text { If we look at innovation in its truest } \\
\text { form, some chaos is necessary. I } \\
\text { absolutely believe - that if we had a } \\
\text { commercial team - then, yes, research } \\
\text { was appropriate but there's no point in } \\
\text { making first rate scientists become } \\
\text { second rate market researchers. }\end{array}$ & $\begin{array}{l}\text { The contrast in how the teams went about it } \\
\text { was amazing. One, the UK, was very } \\
\text { emotional, full of visual appeal and big ideas } \\
\text { and the other (US) was very logical, linear and } \\
\text { methodical and a bit predictable. }\end{array}$ \\
\hline Judge4 & $\begin{array}{l}\text { Go out there, innovate, find the scientific } \\
\text { opportunities - if we like them - then, } \\
\text { fine - we'll go off and do the market } \\
\text { research. But in my view, that's not } \\
\text { what R\&D are there for. They're there } \\
\text { to develop scientific ideas. I think there } \\
\text { should have been far more effort on the } \\
\text { science and only after that has been } \\
\text { developed, evolved should you engage } \\
\text { with consumers. But they spent effort } \\
\text { engaging with consumers despite the fact } \\
\text { that this could have been done better by } \\
\text { professionals. }\end{array}$ & $\begin{array}{l}\text { There was quite a difference between the UK } \\
\text { and the US teams approached the whole thing. } \\
\text { I mean the US had a much more structured } \\
\text { approach, they had dates by which they had to } \\
\text { stop having ideas for example, whereas UK } \\
\text { were effectively having ideas right up to a } \\
\text { couple of days before - they were wide open. }\end{array}$ \\
\hline
\end{tabular}


Table 2. A 'Tale of Two Cities': the UK and US team experience

\begin{tabular}{|c|c|c|}
\hline & UK Team & US Team \\
\hline Team Leader & A Scientist & A Project Manager \\
\hline $\begin{array}{l}\text { Frequency of } \\
\text { Meetings }\end{array}$ & $\begin{array}{l}\text { Infrequent meetings; with full team never actually } \\
\text { meeting. }\end{array}$ & $\begin{array}{l}\text { Team meets twice a week for three hours for duration } \\
\text { of project. }\end{array}$ \\
\hline Process & $\begin{array}{l}\text { - } \quad \text { The only process is 'there is no process!' } \\
\text { - } \quad \text { Engages with several external and internal experts. } \\
\text { - } \quad \text { Commissions external report. } \\
\text { - } \quad \text { Do not do market research to test their ideas. }\end{array}$ & $\begin{array}{l}\text { - Team equipped with dictaphones to capture ideas; } \\
\text { given access to brainstorming software to share } \\
\text { ideas. } \\
\text { - Commissions market research and uses BuzzBack } \\
\text { to rank the ideas. } \\
\text { - } \\
\text { Recruits copywriter and illustrator to develop } \\
\text { presentation of ideas. } \\
\text { - Uses Volumetric research to estimate market size. }\end{array}$ \\
\hline Focus of team & Ideation, with little effort to prioritise ideas. & $\begin{array}{l}\text { Ideation period lasts for first few months and this is } \\
\text { followed by extensive time given to prioritisation. }\end{array}$ \\
\hline $\begin{array}{l}\text { Engagement with } \\
\text { senior management }\end{array}$ & None. & $\begin{array}{l}\text { Team leader brief senior management about the ideas } \\
\text { being pursued. }\end{array}$ \\
\hline $\begin{array}{l}\text { Team member } \\
\text { experiences }\end{array}$ & $\begin{array}{l}\text { Varied by member. Overall: } \\
\text { - } \quad \text { No structure provided'. } \\
\text { - } \quad \text { One or two people do all the 'heavy lifting'. } \\
\text { - } \quad \text { Some senior members back out of the team, they } \\
\text { sense it will end badly. } \\
\text { - } \quad \text { Some members find experience quite stressful. }\end{array}$ & $\begin{array}{l}\text { - Members feel environment and meetings may be } \\
\text { too structured. } \\
\text { - Members find it 'process-heavy' - too many } \\
\text { meetings and very internally focused. } \\
\text { - More project management than creativity. }\end{array}$ \\
\hline Outcomes: judges & $\begin{array}{l}\text { Loses contest; though the majority of the senior } \\
\text { management team consider the UK ideas to be more } \\
\text { radical and on brief. }\end{array}$ & $\begin{array}{l}\text { Winner of RIT tournament. Team generates testable, } \\
\text { research-ready concepts. }\end{array}$ \\
\hline
\end{tabular}


Table 3. Managing the innovation process: UK and US teams

\begin{tabular}{|c|c|c|c|c|}
\hline & \multicolumn{3}{|c|}{ Innovation activities } & \multirow{2}{*}{$\begin{array}{c}\text { Innovation } \\
\text { outcomes }\end{array}$} \\
\hline & Discovering and generating new idea & Choosing among competing ideas & $\begin{array}{c}\text { Embedding the new idea in the } \\
\text { organisation }\end{array}$ & \\
\hline $\begin{array}{l}\text { UK } \\
\text { Team }\end{array}$ & 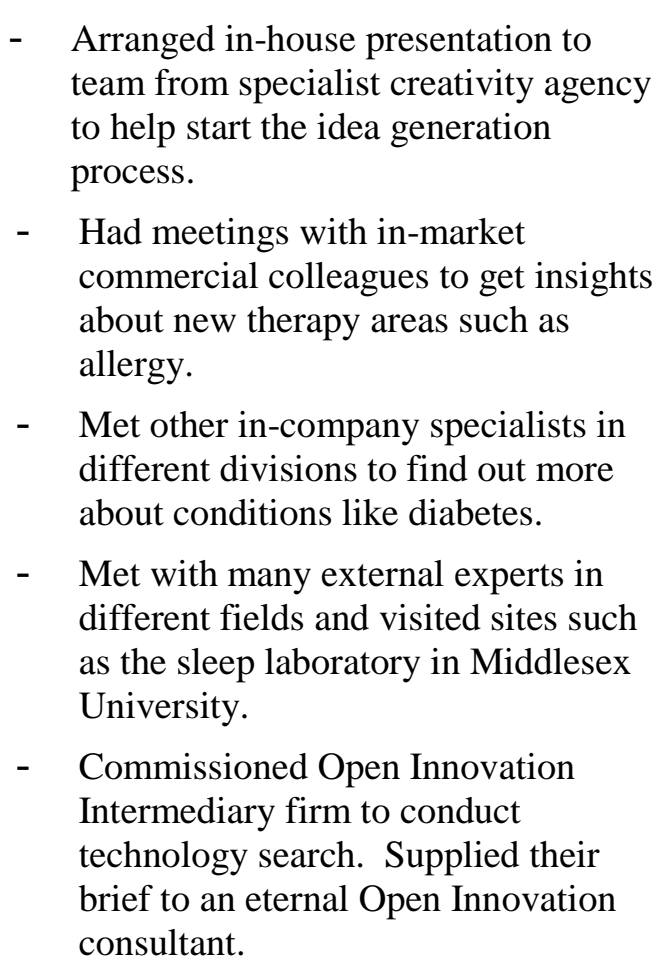 & $\begin{array}{l}\text { - Sole criterion was that if } \\
\text { someone had enthusiasm for the } \\
\text { idea - then it would remain on } \\
\text { the 'shortlist'. Did not screen the } \\
\text { ideas using any other criteria } \\
\text { apart from 'passion'. } \\
\text { - Presented an un-prioritised } \\
\text { selection. No sales estimates } \\
\text { provided or consumer research to } \\
\text { support the ideas. Did not make a } \\
\text { convincing commercial case to } \\
\text { support any single idea. }\end{array}$ & $\begin{array}{l}\text { - Preferred to keep their ideas under } \\
\text { wraps till the final presentation in } \\
\text { order to 'surprise' the judging } \\
\text { panel. Did not attempt to find } \\
\text { champions for their ideas in } \\
\text { advance of the presentation but } \\
\text { merely presented a spectrum of } 27 \\
\text { unranked and un-researched ideas. }\end{array}$ & $\begin{array}{l}13 \text { radical ideas } \\
12 \text { 'new science - } \\
\text { known market' } \\
\text { ideas } \\
1 \text { 'new market- } \\
\text { known science' } \\
\text { idea } \\
0 \text { incremental ideas }\end{array}$ \\
\hline
\end{tabular}


Table 3 cont/d

\begin{tabular}{|c|c|c|c|c|}
\hline & \multicolumn{3}{|c|}{ Innovation activities } & \multirow{2}{*}{$\begin{array}{c}\text { Innovation } \\
\text { outcomes }\end{array}$} \\
\hline & Discovering and generating new idea & Choosing among competing ideas & $\begin{array}{c}\text { Embedding the new idea in the } \\
\text { organisation }\end{array}$ & \\
\hline $\begin{array}{l}\text { US } \\
\text { Team }\end{array}$ & $\begin{array}{l}\text { Provided team with Dictaphones to } \\
\text { record ideas while out of office; they } \\
\text { were shown a (future) trends } \\
\text { presentation from a specialist agency } \\
\text { and they were given access to } \\
\text { innovation software with which they } \\
\text { could record, cluster and rank ideas. } \\
\text { - Stuck to their own group with } \\
\text { dedicated team-room, strong IT } \\
\text { support and regular meetings. Did not } \\
\text { consult widely with other departments } \\
\text { or functions within the business. No } \\
\text { meetings with external experts to } \\
\text { review or discuss their ideas. }\end{array}$ & 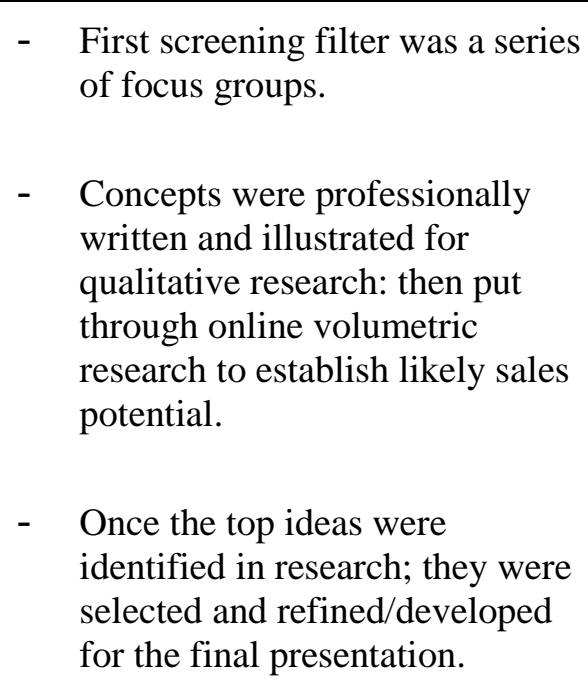 & $\begin{array}{l}\text { - } \begin{array}{l}\text { Continually canvassed the opinions } \\
\text { of SLT about team's ideas. }\end{array} \\
\text { - } \begin{array}{l}\text { Sensitised senior management to } \\
\text { the nature and types of ideas. }\end{array} \\
\text { - Ran 'Ideas Fare' in HQ to exhibit } \\
\text { ideas his team had been working } \\
\text { on. }\end{array}$ & $\begin{array}{l}1 \text { radical idea } \\
3 \text { 'new science - } \\
\text { known market' } \\
\text { ideas } \\
2 \text { 'new market- } \\
\text { known science' } \\
\text { ideas } \\
1 \text { incremental idea }\end{array}$ \\
\hline
\end{tabular}

